\title{
Distribuição da leishmaniose tegumentar por imagens de sensoreamento remoto orbital, no Estado do Paraná, Brasil ${ }^{*}$
}

\section{Tegumentary leishmaniasis distribution by satellite remote sensing imagery, in Paraná State, Brazil}

Airton Pereira Lima ${ }^{1}$

Lorivaldo Minelli

Ueslei Teodoro ${ }^{3}$

Éder Comunello ${ }^{4}$

Resumo: Fundamentos - A leishmaniose tegumentar (LT) tem sua epidemiologia pouco conhecida no Estado do Paraná. ObjEtrvos - Verificar a distribuição geográfica dos casos de LT em quatro municípios do Paraná, usando imagens por sensoriamento remoto orbital (ISRO), correlacionando-a com a presença de vegetação remanescente e cursos d'água.

MÉTodos - A distribuição de 4.416 casos no Paraná, de 1993 a 1998, foi feita com informações da ficha de notificação da Secretaria de Saúde do Estado do Paraná. Por ISRO verificou-se a distribuição de 231 casos de LT e a correlação destes com as matas residuais e o grau de antropia nos municípios de Cianorte, Japurá, Jussara e São Tomé.

Resultados - Houve concentração de casos no Norte e Oeste do Paraná. As ISRO mostram que há relação muito íntima da LT com as áreas de mata nativa modificada, pequenas matas ciliares ou resquícios destas, nos municípios de Cianorte, Japurá, Jussara e São Tomé.

Conclusão - Em Cianorte, Japurá, Jussara e São Tomé a LT tem íntima relação com áreas de mata nativa modificada, pequenas matas ciliares ou resquícios de ambas. Possivelmente, as áreas onde há mais casos de LT no Paraná guardam semelhanças com as desses municípios.

Palavras-chave - ecologia; epidemiologia; leishmaniose mucocutânea.

Summary: Background - The epidemiology of tegumentary leishmaniasis (TL) is poorly known in the State of Paraná. OBJECTIVES - To verify the geographical distribution of TL cases in four municipalities in the State of Paraná and correlate the notified TL cases with the presence of the remaining vegetation and water streams, using images by satellite monitoring. METHODS - The distribution of 4,416 cases of TL in the State of Paraná, from 1993 to 1998, was done according to the notification records used by the State of Parana Health Secretariat. The distribution of 231 cases of TL and the correlation between these cases and the remaining forest, as well as the extent to which man has influenced the environment in Cianorte, Japurá, Jussara and São Tomé municipalities was verified using satellite monitoring

RESULTS - The geographical distribution showed a bigher concentration of cases in the northern and western regions of Paraná. The satellite monitored images show that there is a close relationship between TL and modified native forest areas, gallery forest areas or the remainder of both.

CONCLUSION - It is possible that the areas with higher incidence of TL in Parana are similar to the ones in Cianorte, Japurá, Jussara and São Tomé municipalities.

Key words: ecology; epidemiology; leishmaniasis, mucocutaneous.

\footnotetext{
Recebido em 10.10.2001. / Received in October, $10^{\text {th }}$ of 2001.

Aprovado pelo Conselho Consultivo e aceito para publicação em 22.05.2002. / Approved by the Consultive Council and accepted for publication in May, $22^{\text {nd }}$ of 2002.

* Trabalho realizado nos Departamentos de Medicina e Análises Clínicas da Universidade Estadual de Maringá (DMD/UEM; DAC/UEM) / Work conducted at the Department of Medicine and the Department of Clinical Analysis of the "Universidade Estadual de Maringá (DMD/UEM; DAC/UEM)".

Professor Assistente de Dermatologia. Departamento de Medicina - DMD/UEM / Lecturer of Dermatology, Medicine Department - DMD/UEM.

Prof. Associado de Dermatologia. Centro de Ciências da Saúde da Universidade Estadual de Londrina / Associate Professor of Dermatology. Health Science Center, "Universidade Estadual de Londrina".

${ }^{3}$ Prof. Associado de Parasitologia do Departamento de Análises Clínicas - DAC/UEM / Associate Professor of Parasitology at the Clinical Analysis Department - DAC/UEM

${ }^{4}$ Estudante de Pós-Graduação do Grupo de Estudos Multidisciplinares do Ambiente - UEM / Postgraduate Student, Environmental Multi-Disciplinary Group of Studies - UEM.

@2002 by Anais Brasileiros de Dermatologia
} 


\section{INTRODUÇÃO}

As leishmanioses são doenças causadas por protozoários do gênero Leishmania, Ross 1903, primitivamente transmitidos de mamíferos silvestres (reservatórios) para o homem (hospedeiro) pela picada de flebotomíneos (vetores). São endêmicas nas regiões tropicais da América, África e Índia, nas subtropicais do sudoeste da Ásia e no Mediterrâneo.'

Até meados do século 20 aproximadamente 40 mil casos de leishmaniose foram assinalados em inúmeros pontos do território brasileiro. ${ }^{2}$ Seguiu-se um breve período de quiescência, mas nas duas últimas décadas os casos têm aumentado sensivelmente, segundo notificação de todos os estados., ${ }^{3,4}$ No Brasil, de 1980 a 1988, foram notificados 107.412 casos de leishmaniose tegumentar, em média 11.935 casos por ano. ${ }^{3}$ Houve expressivo crescimento para 310.767 casos, de 1989 a 1999 , em média 28.252 casos por ano. ${ }^{3,4} \mathrm{Na}$ Região Sul, nos últimos 20 anos, foram registrados 6.277 casos, representando $2 \%$ do total de ocorrências no Brasil, e, desses, 6.264 (99,8\%) no Paraná., ${ }^{3,4}$

A leishmaniose tegumentar no Brasil até a década de 1940 estava intimamente relacionada com a penetração do homem em zonas de florestas em desbravamento, pois a derrubada de matas para o plantio, a construção de estradas de rodagem, ferrovias, hidrelétricas e implantação de povoados favoreciam o contato do homem com os reservatórios e vetores de Leishmania. ${ }^{5,6} \mathrm{Na}$ região amazônica, ainda hoje observa-se o padrão epidemiológico de transmissão fundamentado no contato do homem com o ambiente silvestre, onde a doença predomina em indivíduos adultos do sexo masculino.

A persistência da leishmaniose tegumentar de forma endêmica em áreas de colonização antiga tem relação com matas remanescentes modificadas. ${ }^{7-10}$ Nessas áreas é evidente a adaptação de flebotomíneos e reservatórios silvestres de Leishmania, propiciando a formação do ciclo desse parasito no peridomicílio, em zonas rurais e na periferia de centros urbanos. ${ }^{11-16}$

No Estado do Paraná a leishmaniose tegumentar americana vem sendo registrada desde o início do século, com relato de casos até $1958 .^{2,17,18}$ A doença só voltou a ser oficialmente notificada no Paraná a partir de 1980, mantendo-se endêmica em diversos municípios, apesar do desmatamento abusivo ocorrido neste estado. ${ }^{19}$

A vegetação associada a cursos d'água é fator ecológico que tem auxiliado os estudos de distribuição da leishmaniose e a identificação de áreas de risco de infecção, pela análise de paisagens. Linthicum et al..$^{20}$ utilizaram a análise de paisagens por sensoriamento remoto orbital para a delimitação de áreas de ocorrência da febre do Vale do Rift, no Quênia, África. No Brasil, Miranda et al., ${ }^{7,8}$ em imagens obtidas por sensoriamento remoto orbital, observaram a associação da leishmaniose tegumentar com áreas de vegetação arbustiva e a existência de córregos.

A ocorrência de leishmaniose tegumentar tem sido

\section{INTRODUCTION}

Leishmanioses are diseases caused by protozoa of the genus Leishmania, Ross 1903, transmitted primitively from wild mammals (reservoirs) to Man (host) through the bite of phlebotomines (vectors). The disease is endemic in tropical areas of America, Africa and India, as well as in the subtropics of southwest Asia and the Mediterranean. ${ }^{.}$

Up to the mid 20th Century, approximately 40 thousand cases of leishmaniasis were recorded in countless points of the Brazilian national territory. ${ }^{2}$ There was then a brief period of quiescence, but in the last two decades the number of cases has been increasing considerably, according to notifications from all of the states. ${ }^{3,4}$ In Brazil, from 1980 to 1988, 107,412 cases of tegumentary leishmaniasis were notified, representing 11,935 new cases per year. ${ }^{3}$ There was a marked growth from 1989 to 1999, reaching 310,767 cases, or a mean of 28,252 cases per year. ${ }^{3,4}$ In the South Region, in the last 20 years, 6,277 cases were registered, representing 2\% of the total occurrences in Brazil and, of these, 6,264 (99.8\%) were in Paraná State. ${ }^{3,4}$

Until the decade of the 1940's, tegumentary leishmaniasis in Brazil was intimately related to Man's penetration into forested areas, since deforestation to make way for planting, construction of highways and railroads, hydroelectric power stations and implantation of towns favored human contact with the reservoirs and vectors of Leishmania. ${ }^{5,6}$ In the Amazonian region, one can still observe an epidemic pattern of transmission based on the settlers'contact with the wild environment, such that the disease prevails in adult male individuals.

The persistence of tegumentary leishmaniasis in an endemic form within areas of long-standing colonization is related to modification of the remaining forests. ${ }^{7-10}$ In these areas there has been an evident adaptation of phlebotomines and wild reservoirs of Leishmania, propitiating the formation of the cycle of this parasite in the peridomicile, both in rural areas and in the periphery of urban centers. ${ }^{11-16}$

In Paraná State, American tegumentary leishmaniasis has been registered since the beginning of the last century, with cases reported up until 1958., 217,18 The disease was then only notified officially in Paraná as of 1980 and has remained endemic in several municipal districts, despite the abusive deforestation that occurred within this State. ${ }^{19}$

The vegetation associated to water courses is an ecological factor that has been aiding studies into the distribution of leishmaniasis and identification of areas of infection risk, through an analysis of the topography. Linthicum et al. ${ }^{20}$ used analysis of topography by orbital satellite monitoring for the delimitation of areas of occurrence of Rift valley fever in Kenya, Africa. While in Brazil, Miranda et al., ${ }^{7,8}$ used images obtained by orbital satellite monitoring, to determine an association of tegumentary leishmaniasis with areas of bush vegetation and the presence of streams.

The occurrence of tegumentary leishmaniasis has been notified in various municipal districts in Paraná 
notificada em diversos municípios do Estado do Paraná, ${ }^{10,19}$ porém não foi estabelecida nenhuma relação com o nível antrópico e outras variáveis ambientais das regiões abrangidas pelos municípios.

Procurou-se estabelecer neste trabalho: I) a correlação dos casos de leishmaniose tegumentar notificados, no período de 1993 a 1998, nos municípios de Cianorte, Japurá, Jussara e São Tomé, Estado do Paraná, com a presença de vegetação remanescente e cursos d'água nas localidades com maior probabilidade de infecção, utilizando imagens obtidas por sensoriamento remoto orbital; II) a distribuição geográfica dos casos de leishmaniose tegumentar notificados no Estado do Paraná, no período de 1993 a 1998, correlacionando-a com as características ambientais e meteorológicas (vegetação remanescente, precipitação pluviométrica e temperatura) nas diversas regiões do Paraná.

\section{MATERIAL E MÉTODOS}

\section{Descrição Geral do Estado do Paraná}

O Estado do Paraná localiza-se na Região Sul do

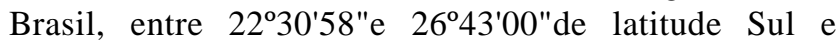
$48^{\circ} 05^{\prime} 37^{\prime \prime}$ e 54 $37^{\prime} 08^{\prime \prime} d e$ longitude Oeste..$^{21}$

Suas cartas climáticas de 1994, elaboradas pelo Instituto Agronômico do Paraná - Iapar, ${ }^{22}$ mostram que há três tipos climáticos no estado, segundo a classificação de Köppen: 1) Af, clima tropical superúmido, sem estação seca, com temperatura média em todos os meses superior a $18^{\circ} \mathrm{C}$ (megatérmico), precipitação média no mês mais seco acima de $60 \mathrm{~mm}$ e isento de geadas; 2) Cfa, clima subtropical; temperatura média no mês mais frio inferior a $18^{\circ} \mathrm{C}$ (mesotérmico) e temperatura média no mês mais quente acima de $22^{\circ} \mathrm{C}$, com verões quentes, geadas pouco freqüentes e tendência de concentração das chuvas nos meses de verão, contudo sem estação seca definida; 3) Cfb, clima temperado propriamente dito; temperatura média no mês mais frio abaixo de $18^{\circ} \mathrm{C}$ (mesotérmico), com verões frescos, temperatura média no mês mais quente abaixo de $22^{\circ} \mathrm{C}$ e sem estação seca definida.

A vegetação primitiva do Paraná, que era constituída por diversos tipos de matas, logo no início do século XX começou a ser destruída para a extração de madeiras, expansão das lavouras cafeeiras e exploração do carvão vegetal. Em menos de meio século, as florestas de cobertura primitiva praticamente desapareceram. Em 1980, delas restavam apenas $5 \%$ e, em 1990 , só $2,6 \%$ da vegetação original, a maioria em parques e áreas de proteção e conservação das matas remanescentes. ${ }^{23}$

\section{Descrição Geral dos Municípios de Cianorte,} Japurá, Jussara e São Tomé

Os municípios de Cianorte, Jussara, Japurá e São Tomé situam-se na mesorregião do noroeste paranaense, entre $52^{\circ} 20^{\prime}$ e $52^{\circ} 50^{\prime}$ longitude Oeste e $23^{\circ} 20^{\prime}$ e $23^{\circ} 60^{\prime}$ latitude Sul (Figura 1). Esses municípios pertencem à unidade geomorfológica do planalto central da bacia do Paraná, ${ }^{24}$
State, ${ }^{10,19}$ however no relationship has been established with the level of anthropic activity nor other environmental variables within the areas covered by these municipal districts.

The objective of this work was to establish: i) a correlation between the notified cases of tegumentary leishmaniasis, in the period from 1993 to 1998, in the municipal districts of Cianorte, Japurá, Jussara and San Tome, Paraná State, with the presence of remaining native vegetation and water courses in the places with a higher infection probability, using images obtained by orbital satellite monitoring; ii) the geographical distribution of the cases of tegumentary leishmaniasis notified in Paraná State, in the period from 1993 to 1998, correlating this with the environmental and meteorological characteristics (remaining native vegetation, annual rainfall and temperature) in the various regions of Paraná.

\section{MATERIAL AND METHODS}

\section{General description of Paraná State}

Paraná State is located in the South Region of

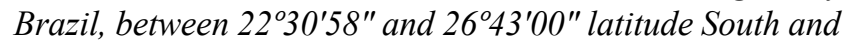
$48^{\circ} 05^{\prime} 37^{\prime \prime}$ and $54^{\circ} 37^{\prime} 08^{\prime \prime}$ longitude West. ${ }^{21}$

The climatic maps of 1994, elaborated by Iapar [Agronomic Institute of Paraná] ${ }^{22}$ show that there are three climatic types in the State, according to Köppen's classification: 1) Af, tropical superhumid climate, without a dry station, with a mean temperature in all months greater than $18^{\circ} \mathrm{C}$ (megathermic), mean precipitation in the driest month over $60 \mathrm{~mm}$ and free from frosts; 2) Cfa, subtropical climate; mean temperature in the coldest month less than $18^{\circ} \mathrm{C}$ (mesothermic) and mean temperature in the hottest month above $22^{\circ} \mathrm{C}$, with hot summers, infrequent frosts and a tendency for a concentration of rainfall in the summer months, however without a defined dry station; and 3) Cfb, temperate climate; mean temperature in the coldest month below $18^{\circ} \mathrm{C}$ (mesothermic), with cool summers, mean temperature in the hottest month below $22^{\circ} \mathrm{C}$ and without a defined dry station.

The primitive vegetation of Paraná was constituted by several types of forests, which at the beginning of the $X X$ century began to be destroyed for the extraction of wood, expansion of coffee plantations and production of charcoal. In less than half a century, the primitive forest covering had practically disappeared. In 1980, there only remained 5\% and, in 1990, a mere $2.6 \%$ of the original vegetation, mostly in parks and areas of protection and conservation of the remaining forests. ${ }^{23}$

\section{General description of the Municipal districts of Cianorte, Japurá, Jussara and San Tome}

The municipal districts of Cianorte, Jussara, Japurá and San Tome are located in the mesoregion of northwest

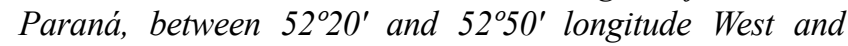
$23^{\circ} 20^{\prime}$ and $23^{\circ} 60^{\prime}$ latitude South (Figure 1). These municipal districts belong to the geomorphological unit of the central 
Figura 1: Localização geográfica dos municípios de Cianorte, Japurá, Jussara e São Tomé.

que é parte do terceiro planalto paranaense ${ }^{25}$ ou planalto arenito-basáltico. O relevo é de planaltos rebaixados, de topos planos e pouco dissecados, com vertentes convexas, compreendido entre as cotas de 250 e $600 \mathrm{~m}$ de altitude, cujo nível de base local é constituído pelo talvegue do médio rio Ivaí, que forma

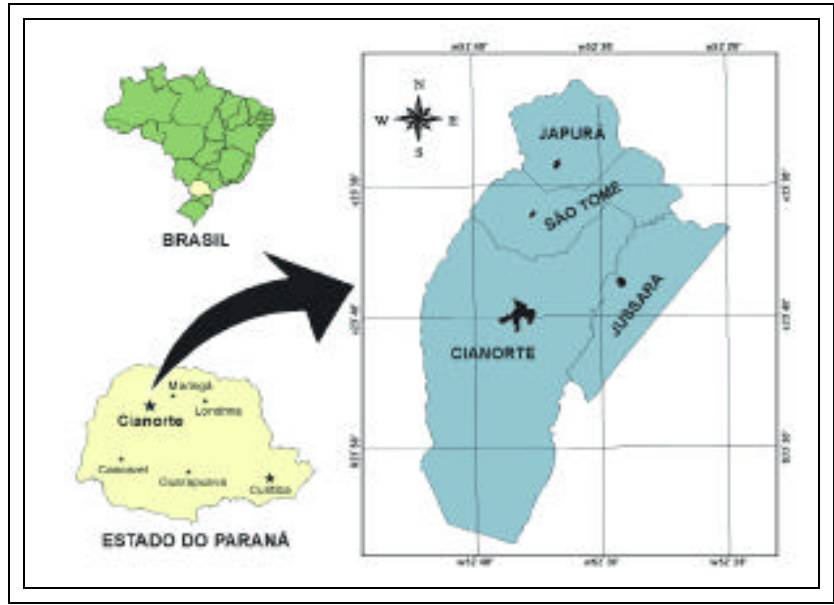

Figure 1: Geographic location of Cianorte, Japurá, Jussara and São Tomé municipalities.

plateau of the Paraná Basin, ${ }^{24}$ which is part of the third Paraná plateau ${ }^{25}$ or sandstone-basaltic plateau. The relief is of lowered plateaus, with flat and little dissected tops, with convex slopes, between 250 and $600 \mathrm{~m}$ of altitude. The local base of which is constituted by the thalweg of the mid river Ivai that forms one uma das principais bacias hidrográficas do noroeste do Paraná. A cobertura original era constituída pela floresta estacional semidecidual. ${ }^{26} \mathrm{O}$ clima é do tipo tropical subquente superúmido com subseca. ${ }^{27} \mathrm{Na}$ fase de subseca de inverno as temperaturas médias são inferiores a $18^{\circ} \mathrm{C}$. A pluviosidade média é de $1.700 \mathrm{~mm} / \mathrm{ano}$.

Nos municípios de Cianorte, Japurá, Jussara e São Tomé a mata original foi largamente alterada ou eliminada, cedendo terreno aos cultivos e ao reflorestamento. Persistem manchas de mata ciliar densa e intrincada, com muitas lianas e taquaras ao longo do rio Ivaí, além de pequenas faixas de mata secundária de largura variável. Observam-se também matas secundárias, que acompanham descontinuamente os cursos d'água constituintes da bacia hidrográfica do Ivaí. Essas formações florestais primárias ou secundárias favorecem a ocorrência de flebotomíneos, sendo um dos fatores ambientais de importância na epidemiologia da leishmaniose tegumentar na região. ${ }^{28}$

A fauna local de mamíferos nativos e possíveis reservatórios de Leishmania é pouco numerosa e variada. As áreas reflorestadas com espécies exóticas e os bosques internamente desbastados atraem poucas espécies animais. As matas ciliares podem abrigar roedores, gambás, cervos e raros felinos. Essas formações apresentam, contudo, fauna de aves numerosa e variada. ${ }^{28}$

A principal atividade econômica nos municípios de Cianorte, Japurá, Jussara e São Tomé é a agricultura, com destaque para as lavouras temporárias e principalmente para os cultivos de soja, cana-de-açúcar, milho e mandioca.

\section{Procedimentos}

A distribuição dos casos de leishmaniose tegumentar notificados nos diversos municípios do Estado do Paraná, as informações sobre faixa etária, sexo, ocupação, área de residência (urbana/rural) e forma clínica da doença foram obtidas do Relatório de Cadastro de Pacientes de Leishmaniose no Estado do Paraná de 1993 a 1996. Parte dos dados de 1997 foram obtidos desse relatório e parte do Sistema de Informação de Agravos de Notificação -Sinan, pois foram identificadas incompatibilidades nas informações dessas of the main hydrographic basins of northwest Paraná. The original covering comprised semidecidual seasonal forest. ${ }^{26}$ The climate type is tropical subhot, superhumid with subdry station. ${ }^{27}$ In the subdry winter station the mean temperatures are under $18^{\circ} \mathrm{C}$. The mean rainfall is $1,700 \mathrm{~mm} /$ year.

In the municipal districts of Cianorte, Japurá, Jussara and San Tome the original forest was extensively altered or eliminated, to provide land for cultivation and reforestation. There still persists remnants of dense ciliary and intricate forest, with many woody lianas and bamboos along the course of the River Ivai, besides small strips of secondary forest of variable breadth. There are also some secondary forests, that uninterruptedly follow the water courses constituting the Ivai hydrographic basin. These primary or secondary forest formations favor the occurrence of phlebotomines and thus are one of the important environmental factors in the epidemiology of tegumentary leishmaniasis within the region. ${ }^{28}$

Local fauna of native mammals and possible reservoirs of Leishmania is sparse with little variety. The areas reforested with exotic species and internally thinned forests attract few animal species. The ciliary forests can shelter rodents, skunks, deer and rare felines. These formations present, however, a numerous and varied fauna of birds. ${ }^{28}$

The main economic activity in the municipal districts of Cianorte, Japurá, Jussara and San Tome is agriculture, mainly for cultivation of soy bean, sugarcane, corn and cassava with a tendency to temporary plantations.

\section{Procedures}

The distribution of the cases of tegumentary leishmaniasis notified in the various municipal districts of Paraná State, information regarding age group, sex, occupation, residential zone (urban/rural) and clinical form of the disease was obtained from the Report of Patients with Leishmaniasis Registered in the State of Parana from 1993 to 1996. Part of the data for 1997 were obtained from this report and the remainder from Sinan [System of Information of Offences of Notification], since irregularities were detected in the information from these registration 
fontes de registro. Os dados de 1998 foram obtidos inteiramente do Sinan. O relatório supracitado e os dados do Sinan foram fornecidos pela Secretaria de Saúde do Estado do Paraná. Além deles, foram utilizadas fichas de notificação e livros de registro das Regionais de Saúde de Cianorte, Londrina, Maringá e Umuarama, da Secretaria de Saúde do Estado do Paraná, para a retificação de informações a respeito das notificações. As notificações de leishmaniose tegumentar no Estado do Paraná de 1993 a 1998 foram analisadas uma a uma, eliminando-se grande número de casos com duplo registro e corrigindo-se a procedência dos mesmos.

A distribuição espacial dos casos de leishmaniose tegumentar nas diversas regiões do Estado do Paraná foi feita segundo os municípios de procedência e de notificação dos pacientes. Foi estabelecida ainda a correlação da distribuição dos casos de leishmaniose com as temperaturas, precipitações pluviométricas e, especialmente, matas.

Na Regional de Saúde de Cianorte foram utilizadas fichas com informações complementares de 231 casos de leishmaniose tegumentar, do total de 382, notificados nos municípios de Cianorte, Japurá, Jussara e São Tomé, de 1993 a 1998. Esses casos foram selecionados conforme os locais de maior probabilidade de ocorrência das infecções, e esses locais definidos com auxílio de plantas contendo a hidrografia, a malha viária, os lotes rurais de cada um dos municípios, incluindo ruas e quadras da zona urbana de Cianorte.

Os casos identificados foram transferidos para o Sistema de Informações Geográficas-SGI/Sitim 2.5, ${ }^{29}$ junto com os temas de relevância para o estudo em questão, tais como hidrografia, limites urbanos e municipais. No SGI/ Sitim realizou-se também a classificação do uso e ocupação do solo em imagem de sensoriamento remoto orbital, referente à órbita-ponto 223-076, com data de passagem em 16 de outubro de 1996.

A imagem, produto do sensor múltiplo TM do satélite Landsat, foi adquirida em formato digital, com nível de correção PL-4 (Processing Level-4), requerendo o georreferenciamento para adquirir propriedades de escala e de projeção.

Como base cartográfica utilizaram-se nos estudos preliminares as cartas planialtimétricas de Umuarama (SF22-Y-C) e Londrina (SF-22-Y-D) na escala 1:250.000, produzidas pelo IBGE. Após a correção geométrica, a imagem foi classificada utilizando-se o algoritmo Maxver. ${ }^{30}$

Nesse ponto, utilizou-se o SGI para cruzar informações a respeito da localização dos casos com os diferentes temas relacionados (classes de uso e ocupação do solo, hidrografia), gerando um mapa preliminar da área de estudo, a partir do qual foi possível definir algumas subáreas de investigação, buscando selecionar aqueles ambientes com maior quantidade de casos de leishmaniose, que poderiam ser habitats apropriados de mamíferos (reservatórios) e vetores (flebotomíneos) de Leishmania. Dessa forma escolheram-se sete quadrantes sources. Data for 1998 were obtained entirely from Sinan. The aforementioned report and data from Sinan were supplied by the General Secretary of Health of Paraná State. Besides these, notification records and registration books from the Regional Health Services of Cianorte, Londrina, Maringá and Umuarama, of the General Secretary of Health of Paraná State, were used for rectification of information regarding the notifications. The notifications of tegumentary leishmaniasis in Paraná State from 1993 to 1998 were analyzed on a one-to-one basis, thereby eliminating a great number of cases with double registration and correcting their origin.

The geographical distribution of the cases of tegumentary leishmaniasis in the various areas of Paraná State was made according to the patients' municipal districts of origin and notification. Furthermore, the correlation was established between the distribution of leishmaniasis cases and temperatures, annual precipitation and especially location of forests.

In the Regional Health Service of Cianorte, files were used with complementary information regarding 231 cases of tegumentary leishmaniasis from a total of 382 cases notified in the municipal districts of Cianorte, Japurá, Jussara and San Tome, from 1993 to 1998. These cases were selected according to the locations with a probability of occurrence of infections, and these places were defined with the aid of maps showing the hydrography, road networks, rural lots of each of the municipal districts, including the streets and blocks in the urban zone of Cianorte.

The cases identified were transferred to the System of Geographical Information-SGI/Sitim 2.5, ${ }^{29}$ together with other aspects of relevance for the study in question, such as hydrography and the urban and municipal limits. The classification of the use and occupation of the soil from the orbital satellite monitoring, regarding orbit-point 223-076, with date of passage on October 16, 1996 was also done using the SGI / Sitim.

The image, produced by the TM multiple sensor of the Landsat satellite, was acquired in digital format, with correction level PL-4 (Processing Level-4), necessitating georeferencing to determine properties of scale and projection.

The preliminary studies used planimetric maps of Umuarama (SF-22-Y-C) and Londrina (SF-22-Y-D) in the scale 1:250,000, produced by IBGE [Brazilian Institute of Geography and Statistics] as the cartographic basis. After geometric correction, the image was classified using the Maxver algorithm..$^{30}$

At this point, the SGI was used to cross-reference information regarding the location of the cases with the various related aspects (classifications for the use and occupation of the soil and hydrography), thereby generating a preliminary map of the study area, starting from which it was possible to define some sub-areas for investigation, with a view to delimiting those environments with a greater number of leishmaniasis cases, which could therefore be appropriate habitats for mammals (reservoirs) and vectors (phlebotomines) of Leishmania. In this manner, seven quadrants 
Figura 2: Delimitação dos quadrantes das áreas de estudo, por imagem de sensoriamento remoto orbital, dos municípios de Cianorte Japurá, Jussara e São Tomé

de $64 \mathrm{~km}^{2}(8 \times 8 \mathrm{~km})$, nominados de A até G. A área de cada quadrante foi definida de maneira a possibilitar a observação dos locais mais prováveis de ocorrência das infecções (Figura 2).

Uma vez definidos os quadrantes de A a G, selecionaram-se os quadrantes A, E, F, G, dos quais algumas áreas foram vistas in loco para confirmar a presença de vegetação e levantar a necessidade da inserção de novas classes de uso e ocupação do solo ou correção das preexistentes.

$\mathrm{Na}$ busca de maior precisão os quadrantes foram retificados, utilizando-se como bases cartográficas folhas na escala 1:100.000 do Departamento de Serviços Geográficos do Exército (SF-22-Y-C-III e VI) e 1:50.000 do Instituto Brasileiro de Geografia e Estatística (SF-22-Y-D-I e IV). Dessa forma foi feita nova classificação da imagem, tendo como subsídios a verificação in loco de localidades da área em estudo.

Ao término das operações supracitadas os dados foram transferidos para o software Spring 3.3, que gerou os mapas finais dos quadrantes, apresentando a demarcação dos casos nos locais de maior probabilidade de ocorrência das infecções e a relação espacial com elementos da paisagem, tais como córregos e vegetação.

Para o conhecimento do nível antrópico, dos padrões de uso do solo e da influência desses fatores na ocorrência da leishmaniose tegumentar no Estado do Paraná realizaram-se o georreferenciamento e a classificação de frações de imagens orbitais do sensor TM Landsat das regiões norte (Cena 221-076 de 24/12/97) e oeste (Cena 223-078 de 10/06/96), destacando-se os municípios com maior ocorrência de casos.

\section{RESULTADOS}

Segundo a tabela 1 observa-se que em 1994 houve maior ocorrência de leishmaniose no Estado do Paraná, no período de 1993 a 1998. Nota-se que dos 4.416 pacientes com leishmaniose tegumentar $2.808(63,6 \%)$ eram do sexo masculino. Em ambos os sexos a faixa etária mais atingida foi a de 21 a 50 anos, com $2.306(52,2 \%)$ casos. A faixa etária de pacientes entre 0 e 10 anos foi a menos atingida.

Na figura 3 observa-se que a distribuição da leishmaniose tegumentar, de 1993 a 1998, ocorreu especialmente nas regiões norte e oeste no Estado do Paraná.
Figure 2: Delimitation of the areas of study quadrants, by satelite remote sensing imagery, of Cianorte, Japurá, Jussara and São Tomé municipalities.

of $64 \mathrm{~km}^{2}(8 \times 8 \mathrm{~km})$ each were selected and denominated $A$ to $G$. The area of each quadrant was defined in such a way as to facilitate the observation of the most probable places of occurrence of infections (Figure 2).

Having defined the quadrants $A$ to $G$, quadrants $A, E, F$ and $G$ were selected, of which some areas were visited in loco to confirm the presence of vegetation and determine the necessity for the elaboration of new classes for the use and occupation of the soil or correction of the preexistent classifications.

In the search for greater precision the quadrants were rectified, using as a basis cartographic sheets in the scale 1:100,000 from the Department of Geographical Services of the Army (SF-22-Y-C-III and VI) and 1:50,000 of the IBGE (SF-22-Y-D-I and IV). In this manner a new classification of the image was made, assisted by the verification in loco of localities within the area under study.

At the end of the above mentioned steps, the data were transferred to the Spring 3.3 software, which generated the final maps of the quadrants, presenting the demarcation of the cases in the places of greater probability for occurrence of infections and the geographical relationship with elements of the landscape: such as streams and vegetation.

To ascertain the anthropic activity level, the patterns of soil usage and influence of these factors in the occurrence of the tegumentary leishmaniasis in Parana State, the region was georeferenced with classification of fractions of orbital images from the TM Landsat sensor of the north areas (Scene 221-076 taken on 12/24/97) and west (Scene 223-078, 06/10/96), highlighting the municipal districts with greater occurrence of cases.

\section{RESULTS}

As shown in table 1, there was a greater occurrence of leishmaniasis in Paraná State in 1994, during the period from 1993 to 1998. It was observed that of the 4,416 patients with tegumentary leishmaniasis 2,808 (63.6\%) were male. For both sexes the age group most affected was 21 to 50 years old, accounting for 2,306 (52.2\%) cases. The age group of patients' between 0 and 10 years was the least involved.

Figure 3 shows that the distribution of tegumentary leishmaniasis, from 1993 to 1998, occurred especially in the north and west areas of Paraná State. 
Tabela 1: Faixa etária e sexo de pacientes com leishmaniose tegumentar no Estado do Paraná, de 1993 a 1998 Table 1: Age-group and sex of patients with tegumentary leishmaniasis in Paraná State, from 1993 to 1998

\begin{tabular}{|c|c|c|c|c|c|c|c|c|c|c|c|c|c|c|c|}
\hline \multirow{2}{*}{$\begin{array}{l}\text { Ano / Year } \\
\text { Faixa Etária / Age group }\end{array}$} & \multirow[b]{2}{*}{ Sexo } & \multicolumn{2}{|c|}{1993} & \multicolumn{2}{|c|}{1994} & \multicolumn{2}{|c|}{1995} & \multicolumn{2}{|c|}{1996} & \multicolumn{2}{|c|}{1997} & \multicolumn{2}{|c|}{1998} & \multicolumn{2}{|c|}{ Total } \\
\hline & & $\mathrm{N}$. & $\%$ & $\mathrm{~N}$. & $\%$ & N. & $\%$ & N. & $\%$ & N. & $\%$ & N. & $\%$ & N. & $\%$ \\
\hline \multirow[t]{2}{*}{$0 \mathrm{a} /$ to 10} & M & 40 & 4,9 & 51 & 4 & 21 & 2,8 & 21 & 3,4 & 14 & 2,8 & 14 & 3,2 & 161 & 3,7 \\
\hline & F & 36 & 4.4 & 36 & 2,8 & 18 & 2,4 & 15 & 2,5 & 14 & 2,8 & 15 & 3,5 & 134 & 3 \\
\hline \multirow[t]{2}{*}{$11 \mathrm{a} /$ to 20} & M & 73 & 9 & 135 & 10,5 & 59 & 7,8 & 49 & 8 & 35 & 6,9 & 36 & 8,3 & 387 & 8,8 \\
\hline & $\mathrm{F}$ & 58 & 7,1 & 105 & 8,1 & 40 & 5,3 & 38 & 6,2 & 20 & 3,9 & 11 & 2,5 & 272 & 6,2 \\
\hline \multirow[t]{2}{*}{$21 \mathrm{a} /$ to 35} & M & 146 & 17,9 & 212 & 16,4 & 159 & 21,1 & 135 & 22 & 92 & 18 & 74 & 17,1 & 818 & 18,5 \\
\hline & $\mathrm{F}$ & 70 & 8,6 & 142 & 11 & 69 & 9,2 & 51 & 8,3 & 40 & 7,8 & 40 & 9,3 & 412 & 9,3 \\
\hline \multirow[t]{2}{*}{$36 \mathrm{a} /$ to 50} & M & 127 & 15,6 & 189 & 14,6 & 129 & 17,1 & 104 & 16,9 & 80 & 15,7 & 73 & 16,9 & 702 & 15,9 \\
\hline & $\mathrm{F}$ & 70 & 8,6 & 109 & 8,4 & 63 & 8,4 & 54 & 8,8 & 42 & 8,2 & 36 & 8,3 & 374 & 8,5 \\
\hline \multirow[t]{2}{*}{$51 \mathrm{a} /$ to 65} & M & 84 & 10,3 & 128 & 9,9 & 84 & 11,5 & 56 & 9,1 & 70 & 13,7 & 56 & 12,9 & 478 & 10,8 \\
\hline & $\mathrm{F}$ & 50 & 6,1 & 89 & 6,9 & 42 & 5,6 & 29 & 4,7 & 30 & 5,9 & 37 & 8,6 & 277 & 6,3 \\
\hline \multirow[t]{2}{*}{66 ou / or +} & M & 34 & 4,2 & 49 & 3,8 & 33 & 4,4 & 37 & 6 & 39 & 7,6 & 30 & 6,9 & 222 & 5 \\
\hline & $\mathrm{F}$ & 22 & 2,7 & 34 & 2,6 & 20 & 2,7 & 17 & 2,8 & 17 & 3,3 & 11 & 2,5 & 121 & 2,7 \\
\hline \multirow[t]{2}{*}{ Ignorado / Unknown } & M & 03 & 0,4 & 08 & 0,6 & 11 & 1,5 & 05 & 0,8 & 13 & 2,6 & - & - & 40 & 0,9 \\
\hline & $\mathrm{F}$ & 02 & 0,2 & 05 & 0,4 & 04 & 0,5 & 03 & 0,5 & 04 & 0,8 & - & - & 18 & 0,4 \\
\hline \multirow[t]{2}{*}{ Subtotal / Subtotal } & M & 507 & 62,2 & 772 & 59,8 & 496 & 66 & 407 & 66,3 & 343 & 67,3 & 283 & 65,4 & 2.808 & 63,6 \\
\hline & $\mathrm{F}$ & 308 & 37,8 & 520 & 40,2 & 256 & 34 & 207 & 33,7 & 167 & 32,7 & 150 & 34,6 & 1.608 & 36,4 \\
\hline Total & & 815 & 100 & 1.292 & 100 & 752 & 100 & 614 & 100 & 510 & 100 & 433 & 100 & 4.416 & 100 \\
\hline
\end{tabular}

Fonte: Secretaria de Saúde do Estado do Paraná/ISEP/Cepi. / Source: Health Secretary of Paraná State /ISEP/Cepi.

Aproximadamente $94 \%$ dos casos de leishmaniose tegumentar do estado ocorreram nas regiões com clima do tipo Cfa, e mais de $96 \%$ nas regiões com temperatura média anual acima de $18^{\circ} \mathrm{C}$. Houve predomínio de leishmaniose nas áreas em que as médias anuais das temperaturas mínimas e máximas são acima de $14^{\circ} \mathrm{C}$ e acima de $25^{\circ} \mathrm{C}$, respectivamente, o que abrange as regiões norte e oeste do Estado do Paraná (Figura 3).

O maior número de notificações da doença (acima de 90\% dos casos) ocorreu nas regiões cuja média anual da umidade relativa do ar oscilou entre 70 e $75 \%$, e praticamente a totalidade dos casos registrados ocorreu em áreas com precipitação pluviométrica (total médio anual) variando de 1.300 a $2.000 \mathrm{~mm}$.

Verificou-se que os casos de leishmaniose tegumentar estão distribuídos em 276 municípios no Estado do Paraná, da seguinte forma: em $173(62,8 \%)$ foram notificados de um a nove casos, em $62(22,5 \%)$ de 10 a 24 , em $23(8,3 \%)$ de 25 a 49 , em $11(4 \%)$ de 50 a 99 e em sete $(2,5 \%) 100$ ou mais.
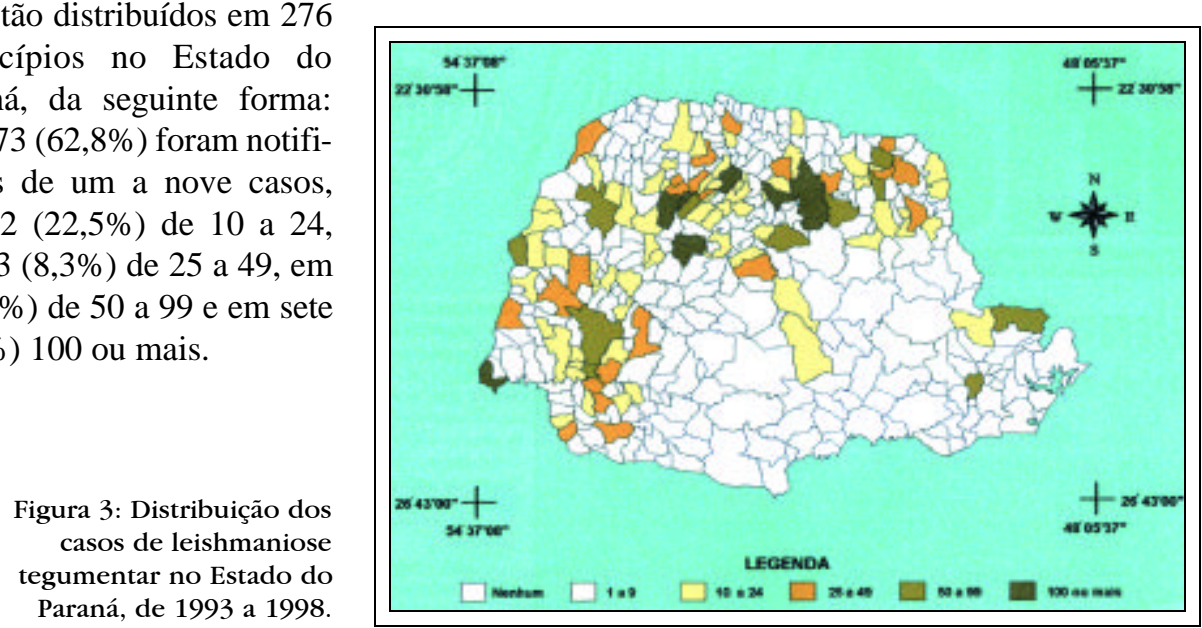

Approximately $94 \%$ of the tegumentary leishmaniasis cases in the State occurred in those areas with a Cfa type climate and more than $96 \%$ in areas with annual medium temperature above $18^{\circ} \mathrm{C}$. There was a prevalence of leishmaniasis in areas in which the annual means of the minimum and maximum temperatures were over $14^{\circ} \mathrm{C}$ and above $25^{\circ} \mathrm{C}$, respectively, which includes the areas in the north and west of Paraná State (Figure 3).

The largest number of notifications of the disease (above $90 \%$ of the cases) originated in those areas in which the annual average of relative humidity of the air oscillated between 70 and $75 \%$, and practically all the registered cases occurred in areas with mean annual precipitation from 1,300 to 2,000mm.

The mentioned cases of tegumentary leishmaniasis were distributed in 276 municipal districts in the State of Paraná, as follows: in 173 (62.8\%) one to nine cases were notified; in $62(22.5 \%)$ from 10 to 24; in 23 (8.3\%) from 25 to 49; in 11 (4\%) from 50 to 99; and in seven (2.5\%) 100 or more.

Figure 3: Distribution of Tegumentary Leishmaniasis cases in the State of Paraná, from 1993 to 1998. 
Nos quadrantes de A a G (Figura 2), abrangendo os municípios de Cianorte, Japurá, Jussara e São Tomé, foram assinalados 60, 22, 82 e 17 casos de leishmaniose tegumentar, respectivamente.

$\mathrm{Na}$ área urbana de Cianorte (Figura 4) assinalaramse 37 casos nos locais de maior probabilidade de ocorrência da infecção por Leishmania, bem como outros cinco fora dos limites da área urbana.

Nas figuras 5 e 6 nota-se a demarcação de 59 e 27 casos, respectivamente, com três demarcados na área de intersecção dessas figuras e um no Município de Cianorte, totalizando 82 casos pertencentes ao Município de Jussara e demarcados nos locais ou áreas de maior probabilidade de infecção.

Nas frações de imagens orbitais do sensor TM Landsat observou-se que nos municípios em que ocorreram numerosas notificações de leishmaniose tegumentar, de 1993 a 1998, na região norte do Paraná, houve extrema devastação do meio ambiente, persistindo matas nativas de pequeno porte ou resquícios delas. $\mathrm{O}$ mesmo fato vale para os municípios da região oeste do Paraná.

\section{DISCUSSÃO}

O maior número de casos de leishmaniose em adultos do sexo masculino está provavelmente relacionado ao trabalho rural próximo a matas e a atividades de lazer (principalmente a pesca) nas margens de rios e córregos com matas ciliares que, embora alteradas, mantêm o ciclo enzoótico de Leishmania. De 147 indivíduos com a doença e residentes em Maringá, 44 (39 homens) se referiram às margens do rio Ivaí, onde costumavam pescar, como o mais provável local de infecção. Os resultados da presente investigação confirmam estudos anteriores que demonstraram a predominância da leishmaniose tegumentar no sexo masculino, ${ }^{31,32}$ incluídos os referentes ao Estado do Paraná. ${ }^{10,33}$

Os casos relativos a mulheres e a crianças do sexo masculino, embora em menor proporção (40,1\%), são expressivos e devem-se mais provavelmente às atividades rurais desenvolvidas pela mão-de-obra do sexo feminino, bem como ao hábito comum de casas e abrigos de animais domésticos serem construídos ao lado de matas nativas modificadas, cujo ambiente é mais fresco e agradável. ${ }^{10}$ Geralmente as habitações são construídas próximo às nascentes de rios e córregos com matas ciliares, em função da

Figura 4: Quadrante E da figura 2. Demarcação dos casos de leishmaniose tegumentar nos locais de maior probabilidade de infecção, na periferia da zona urbana de Cianorte, de 1993 a 1998.
In the quadrants of A to G (Figure 2), including the municipal districts of Cianorte, Japurá, Jussara and San Tome, 60, 22, 82 and 17 cases of tegumentary leishmaniasis were recorded, respectively.

In the urban area of Cianorte (Figure 4) 37 cases were registered in the places with highest probability of occurrence of infection by Leishmania, as well as another five cases outside the limits of the urban area.

In Figures 5 and 6 it can be seen that there were 59 and 27 cases, respectively, with three demarcated within the area of intersection of these figures and one in the Municipal district of Cianorte, totaling 82 cases in the Municipal district of Jussara and demarcated in the places or areas with the highest probability of infection.

In the fractions of orbital images from the TM Landsat sensor it was observed that in the municipal districts in which there were numerous notifications of tegumentary leishmaniasis, from 1993 to 1998, in the north area of Paraná, there had occurred an extreme devastation of the environment, with only small areas or traces of native forests remaining. The same is also true for the municipal districts in the west of Paraná.

\section{DISCUSSION}

The greater number of cases of leishmaniasis involving male adults is probably related to rural work close to forests and to leisure activities (mainly fishing) along the margins of rivers and streams with ciliary forests that, although altered, still maintain the enzootic cycle of Leishmania. Of 147 individuals with the disease and resident in Maringá, 44 (39 men) referred to the margins of the river Ivai, where they fish, as being the most probable place in which they acquired the infection. The results of the present investigation confirm previous studies that demonstrated the males sex bias in tegumentary leishmaniasis, ${ }^{31,32}$ including those focussing Paraná State..$^{10,33}$

The cases relative to women and male children, although in a smaller proportion (40.1\%), are expressive and most probably due to rural activities undertaken by female labor, as well as the common habit of building houses and shelters for domestic animals alongside modified native

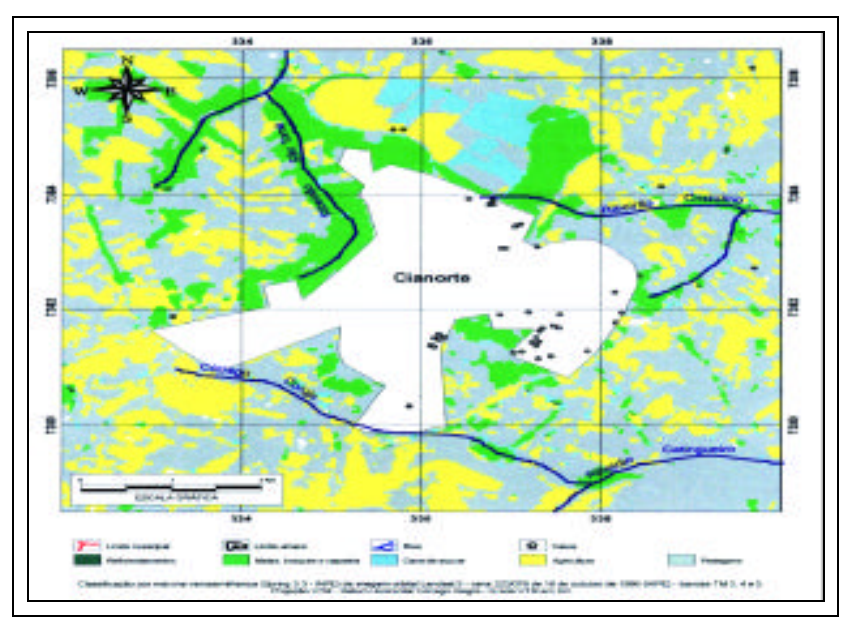
forests, where the atmosphere is fresher and more agreeable. ${ }^{10}$ Usually the houses are built close to the banks of rivers and streams with ciliary forests, in order to facilitate the provision of water for human consump-

Figure 4: Quadrant E from figure 2. Delimitation of Tegumentary Leishmaniasis cases in the places of higher probability of infection, in the periphery of the urban center of Cianorte, from 1993 to 1998. 
maior facilidade de obtenção de água para o consumo humano e de animais domésticos. ${ }^{10} \mathrm{~A}$ infecção de mulheres e crianças é um forte indício de transmissão domiciliar e/ou peridomiciliar de Leishmania, o que tem sido reforçado pela verificação de elevadas densidades de flebotomíneos no domicilio e, particularmente, em abrigos de animais domésticos no peridomicílio de áreas endêmicas dos estados de Pernambuco, ${ }^{34}$ Espírito Santo, ${ }^{14}$ São Paulo, ${ }^{35,36}$ e Paraná. $.8,37$

Houve notificação de leishmaniose em 276 municípios do Paraná. Contudo, sabe-se que há concentração de notificação da doença nos municípios que servem como sede das regionais de saúde da Secretaria de Saúde do Estado do Paraná, uma vez que o tratamento vem sendo feito, em regra, nos serviços de dermatologia desses municípios. A retificação de informações das notificações feitas nos municípios de Cianorte, Londrina, Maringá e Umuarama permitiu verificar que diversos casos de pessoas residentes em outros municípios foram notificados como referentes a residentes naqueles municípios. E mesmo entre as pessoas residentes nos municípios acima nominados muitas não eram autóctones. No caso de Curitiba, verificou-se que, apesar do elevado número de casos notificados, não há relato de casos autóctones. Esses fatos comprovam a existência de falhas de notificação da doença no Paraná.

A maioria dos municípios com ocorrência de leishmaniose tegumentar está na área de domínio de clima Cfa da classificação de Köeppen (clima subtropical), com predomínio nas faixas de temperatura média anual superior a $18^{\circ} \mathrm{C}$, localizando-se os municípios com maior número de casos (acima de 100 no período considerado) nas faixas de isotermas médias anuais entre 20 e $22^{\circ} \mathrm{C}$.

Aproximadamente $94 \%$ dos casos de leishmaniose tegumentar no Estado do Paraná ocorreram nas regiões com clima do tipo Cfa, e mais de $96 \%$ nas regiões com temperatura média anual acima de $18^{\circ} \mathrm{C}$. Houve predomínio de leishmaniose nas áreas em que a média anual das temperaturas mínimas é acima de $14^{\circ} \mathrm{C}$, e a média anual das temperaturas máximas acima de $25^{\circ} \mathrm{C}$, que abrangem as regiões norte e oeste do Estado do Paraná (Figura 1). No Estado de São Paulo, de 1986 a 1995, Camargo-Neves ${ }^{9}$ observou que $76 \%$ dos municípios com notificação de leishmaniose encontram-se na faixa de isotermas médias anuais de 19 a $23^{\circ} \mathrm{C}$, com os maiores coeficientes de incidência na faixa de temperatura entre 21 e $23^{\circ} \mathrm{C}$. Em Corte de Pedra, Bahia, em área de ocorrência de leishmaniose, a temperatura variou entre 16 e $37^{\circ} \mathrm{C}$, com média anual de $22^{\circ} \mathrm{C},{ }^{38}$ corroborando os dados deste trabalho.

Nas regiões de ocorrência do maior número de notificações de leishmaniose tegumentar observou-se que a umidade relativa do ar (média anual) ficou entre 70 e $75 \%$. Nota-se ainda que a quase totalidade dos casos ocorreu em áreas com precipitação pluviométrica que oscilou de 1.300 a 1.900mm (média anual). Os municípios com maior número de registros de casos da doença se localizam em áreas com precipitação de chuva variável de 1.500 a $1.800 \mathrm{~mm}$. $\mathrm{Na}$ área endêmica de Corte de Pedra, Bahia ${ }^{38}$ foi observada tion and domestic animals. ${ }^{10}$ The infection of women and children is a strong indication of domiciliary and/or peridomiciliary transmission of Leishmania, which has been reinforced by the verification of high densities of phlebotomines in the home and especially in shelters for domestic animals in the peridomicile of endemic areas in the states of Pernambuco, ${ }^{34}$ Espírito Santo, ${ }^{14}$ São Paulo, ${ }^{35,36}$ and Paraná. ${ }^{28,37}$

Leishmaniasis was notified in 276 municipal districts of Paraná. However, it is known that there is a tendency to concentrate notification of the disease in the municipal districts that serve as head offices for the regional health services of the General Secretary of Health of the State of Paraná, since treatment is provided, as a rule, in the dermatology services of these municipal districts. Rectification of information regarding notifications from the municipal districts of Cianorte, Londrina, Maringá and Umuarama enabled the conclusion that several cases of people resident in other municipal districts were erroneously notified as being resident in these municipal districts. And even among the patients resident in the abovementioned municipal districts many were not autochthonous. In the case of Curitiba, it was found that, in spite of the high number of notified cases, there were no reports of autochthonous cases. These facts demonstrate the existence of flaws in the notification of the disease in Paraná.

The majority of the municipal districts with occurrence of tegumentary leishmaniasis are in the area with a Cfa climate, according to Köeppen's classification (subtropical climate), with bands of annual mean temperature predominantly over $18^{\circ} \mathrm{C}$, while the municipal districts with the highest number of cases (above 100 in the period considered) are located in the bands of annual mean isotherms between 20 and $22^{\circ} \mathrm{C}$.

Approximately $94 \%$ of the cases of tegumentary leishmaniasis in Paraná State occurred in areas with a Cfa climate, and more than $96 \%$ in areas with annual mean temperature above $18^{\circ} \mathrm{C}$. There was a prevalence of leishmaniasis in areas in which the annual mean minimum temperature is over $14^{\circ} \mathrm{C}$, and the annual mean maximum temperature above $25^{\circ} \mathrm{C}$, which includes areas in the north and west of Paraná State (Figure 1). In São Paulo State, from 1986 to 1995, Camargo-Neves ${ }^{9}$ observed that $76 \%$ of the municipal districts notifying leishmaniasis were in the band of annual mean isotherms from 19 to $23^{\circ} \mathrm{C}$, with the highest incidence of coefficients in the temperature band between 21 and $23^{\circ} \mathrm{C}$. In Corte de Pedra, Bahia, an area with occurrence of leishmaniasis, the temperature varied from 16 to $37^{\circ} \mathrm{C}$, with an annual mean of $22^{\circ} \mathrm{C},{ }^{38}$ corroborating the data of this work.

In the areas with the highest number of notifications of tegumentary leishmaniasis it was observed that the relative humidity of the air (annual mean) was between 70 and $75 \%$. It was also noted that almost all the cases occurred in areas with a mean annual precipitation that oscillated from 1,300 to 1,900mm. The municipal districts with the highest number of registrations of the disease were located in areas with rainfall from 1,500 to 1,800mm. In the endemic area of 
a média anual de $1.300 \mathrm{~mm}$ de chuva e umidade média de 78\%. Camargo-Neves, ${ }^{9}$ no Estado de São Paulo, verificou maior coeficiente de incidência de leishmaniose tegumentar nas áreas com quedas de chuva superior a $1.500 \mathrm{~mm}$, embora o maior número de municípios com notificação da doença se localizasse na faixa de 1.300 a $1.500 \mathrm{~mm}$ de chuva.

Na Figura 2, nos quadrantes A a G, estão demarcados os locais de residência de pacientes dos municípios de Japurá, Cianorte e São Tomé. Coincidentemente os locais de maior possibilidade de infecção estão muito próximo de cursos d'água com matas ciliares arbustivas ou resíduos de matas primitivas.

Os casos de leishmaniose notificados na zona urbana de Cianorte (Figura 4) tiveram como locais de maior probabilidade de infecção o domicílio e peridomicílio, uma vez que as casas se situam nas proximidades ou nas margens de matas nativas modificadas. A maior concentração dos casos ocorreu onde a mata apresenta maior grau de alteração, dentro da área denominada Cinturão Verde de Cianorte.

A Fazenda Jussara, no Município de Jussara, foi indicada como o local mais provável de infecção dos 37 casos assinalados na Figura 5. Deles, 11 tiveram como local com grande probabilidade de infecção a área conhecida como horto florestal, constituída por um núcleo de habitações (colônia) ao lado do córrego do Encontro; mais dois casos na destilaria e dois na porteira principal da fazenda. Os 22 casos restantes da Fazenda Jussara ocorreram com certeza em seus limites, embora não tenha sido possível determinar mais especificamente os locais prováveis de infecção. Os demais casos (22) da Figura 5 referem-se aos locais de residência próximo a cursos d'água com manchas ou resquícios de matas ou ao lado das matas de maior porte da Fazenda Jussara.

Os 21 casos agrupados na Figura 6 têm como possível local de infecção a Olaria Andirá. A maioria das infecções ocorreu muito provavelmente no domicílio e peridomicilio.

Ressalte-se que na Fazenda Jussara e na Olaria Andirá, onde houve grande concentração de casos, há áreas extensas de mata que, embora modificada, preserva muitas das características da mata nativa que existia na região.

No Estado de São Paulo, em

Figura 5: Quadrante F da figura 2. Demarcação dos casos de leishmaniose tegumentar nos locais de maior probabilidade de infecção, no município de Jussara, de 1993 a 1998.
Corte de Pedra, Bahia, ${ }^{38}$ an annual average of 1,300mm of rainfall and mean humidity of $78 \%$ was observed. Camargo-Neves, ${ }^{9}$ found a higher coefficient of incidence of tegumentary leishmaniasis in areas of São Paulo State with annual rainfall greater than 1,500mm, although the majority of municipal districts with notification of the disease were located in the band with 1,300 to 1,500mm of rainfall.

Figure 2 shows the locations in quadrants A to $G$ of the patients' homes in the municipal districts of Japurá, Cianorte and San Tomé. It can be seen that the areas with the highest probability of infection coincide with proximity to water courses with shrub ciliary forests or remnants of primary forests.

The cases of leishmaniasis notified in the urban area of Cianorte (Figure 4) revealed the home and peridomicile be the places with the greatest probability of infection, since the houses are generally located close to or alongside the margins of modified native forests. The largest concentration of cases occurred where the forest presents the greatest degree of alteration, within the area denominated the Green Belt of Cianorte.

Fazenda Jussara, in the Municipal district of Jussara, was indicated as the most probable place of infection among the 37 cases marked in figure 5. Of these, 11 occurred in the area with the greatest risk of infection known as the horto florestal [forest reserve], constituted by a nucleus of houses (colony) beside the Encontro stream; plus two cases in the distillery and two in the main gate of the farm. The 22 remaining cases in Fazenda Jussara certainly occurred within its limits, although it was not possible to determine the probable site of infection more specifically. The other cases (22) shown in Figure 5 refer to the location of domiciles close to water courses with remnants or traces of forests or beside the larger forests of Fazenda Jussara.

The 21 cases contained in Figure 6 refer to a possible site of infection called Olaria Andirá. Most of the infections

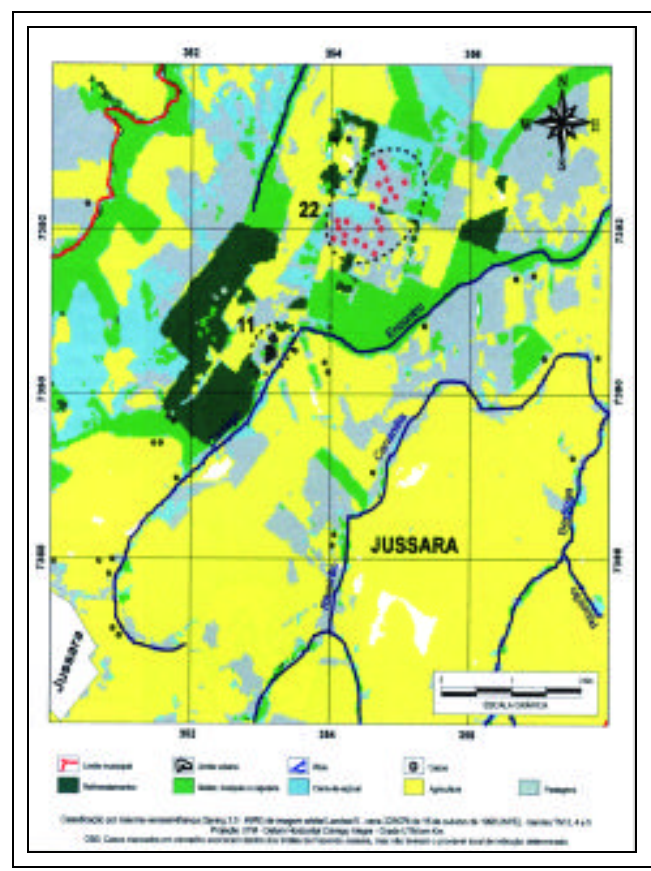
very probably occurred in the home or peridomicile.

It should be underscored that in Fazenda Jussara and Olaria Andirá, where there was a great concentration of cases, there are extensive areas of forest that, although modified, still preserve many of the characteristics of the native forest that existed in the region.

In São Paulo State, using images obtained by orbital satellite monitoring, Miranda et al. ${ }^{7.8}$ showed the presence of shrub vegeta-

Figure 5: Quadrant $F$ from figure 2. Delimitation of Tegumentary Leishmaniasis cases in the places of bigher probability of infection in the municipal district of Jussara, from 1993 to 1998 
Figura 6: Quadrante $G$ da figura 2. Demarcação dos casos de leishmaniose tegumentar nos locais de maior probabilidade de infecção, no município de Jussara, de 1993 a 1998.

imagens obtidas por sensoriamento remoto orbital, Miranda et al. ${ }^{7,8}$ mostraram a presença de vegetação arbustiva próximo às localidades em que pessoas notificadas com leishmaniose residiam e/ou trabalhavam. Ainda no Estado de São Paulo Camargo-Neves ${ }^{9}$ demonstrou que os tipos de vegetação natural de capoeira, resíduo de mata e de mata preservada ocorreram nas áreas de verificação dos maiores coeficientes de incidência da leishmaniose tegumentar.

As imagens por sensoriamento remoto orbital mostram que nos municípios de Cianorte, Japurá, Jussara e São Tomé a leishmaniose tegumentar tem relação muito íntima com áreas de mata nativa modificada, pequenas matas ciliares ou seus resquícios e/ou com a área domiciliar e peridomiciliar.

A maioria dos casos de leishmaniose tegumentar no Estado do Paraná foi notificado em municípios das regiões norte e oeste, coincidindo com as áreas em que houve intensa destruição da vegetação nativa. Possivelmente, os ambientes em que está ocorrendo a infecção por Leishmania nas regiões supracitadas se assemelham aos observados nos municípios de Cianorte, Japurá, Jussara e São Tomé.

\section{CONCLUSÕES}

1. A leishmaniose tegumentar no Estado do Paraná tem distribuição geográfica ampla e irregular, com concentração de casos em municípios das regiões norte e oeste, coincidindo com áreas de alto grau de destruição da vegetação nativa, em decorrência da exploração agrícola por monoculturas, especialmente de milho, soja e cana-de-açúcar, e pastagens; nessas regiões a temperatura média anual fica acima de $18^{\circ} \mathrm{C}$, a umidade relativa do ar oscila entre 70 e $75 \%$, e a precipitação pluviométrica média anual varia de 1.300 a $1.900 \mathrm{~mm}$.

2. As imagens por sensoriamento remoto orbital mostram que nos municípios de Cianorte, Japurá, Jussara e São Tomé a leishmaniose tegumentar tem relação muito íntima com áreas de mata nativa modificada, pequenas matas ciliares ou resquícios delas.
Figure 6: Quadrant G from figure 2. Delimitation of Tegumentary eishmaniasis cases in the places of higher probability of infection in the municipal district of Jussara, from 1993 to 1998.

tion close to the places in which people notified with leishmaniasis lived and/or worked. Also in São Paulo State Camargo-Neves ${ }^{0}$ demonstrated that the natural vegetation types of capoeira (tall, dense grasslands), residual forest and preserved forest occurred in the areas in which they verified the highest coefficients of incidence of tegumentary leishmaniasis.

The images from orbital satellite monitoring show that regarding tegumentary leishmaniasis in the municipal districts of Cianorte, Japurá, Jussara and San Tome, there is a very close relationship between areas of modified native forest, small ciliary forests or remnants of which and the home and/or peridomicile.

Most of the cases of tegumentary leishmaniasis in Paraná State were notified in municipal districts of the north and west areas, coinciding with the areas in which there was intense destruction of the native vegetation. It is possible that the environments in which infection by Leishmania is occurring in the above mentioned areas resemble those observed in the municipal districts of Cianorte, Japurá, Jussara and San Tome.

\section{CONCLUSIONS}

1. Tegumentary leishmaniasis in Paraná State has an extensive and irregular geographical distribution, with concentration of cases in municipal districts of the north and west regions, coinciding with areas marked by a high degree of destruction of the native vegetation, due to agricultural exploration by monoculture, especially corn, soy bean, sugarcane, and also pastures; in those areas the annual mean temperature is above $18^{\circ} \mathrm{C}$, relative humidity of the air varies between 70 and $75 \%$, and the annual mean rainfall varies from 1,300 to 1,900mm.

2. Images from orbital satellite monitoring show that in the municipal districts of Cianorte, Japurá, Jussara and San Tome tegumentary leishmaniasis has a very close relationship with areas of modified native forest, small ciliary forests or remnants of these.

\section{REFERÊNCIAS / REFERENCES}

1. Modabber F. Leishmaniasis. In: UNDP. World Bank. WHO. Special programme for tesearch and training in tropical diseases (TDR). Tropical Desease Research: progress 1991-92, Geneva: World Health Organization 1993;77-87.

2. Pessôa SB, Barreto MP. Leishmaniose tegumentar americana. Rio de Janeiro: Ministério da Educação e Saúde. Imprensa Nacional, 1948. 3. Ministério da Saúde. Fundação Nacional de Saúde. Série histórica de casos de agravos e doenças infecciosas e parasitárias- 
Brasil-1980 a 1996. Informe Epidemiológico do SUS 1997, anoVI(1):59-60.

4. Ministério da Saúde (Fundação Nacional de Saúde). Manual de controle da leishmaniose tegumentar americana. Brasília, 2000.62p.

5. Forattini OP. Entomologia médica. São Paulo: E. Blücher/EDUSP, 1973:4v.658p.

6. Souza AM, Geller M. Abordagem epidemiológica, clínica e laboratorial da leishmaniose tegumentar americana. Folha Médica 1994;108(3):53-7.

7. Miranda C, Massa JL, Marques CCA. Análise da ocorrência de leishmaniose tegumentar americana através de imagem obtida por sensoriamento remoto orbital em localidade urbana da região Sudeste do Brasil. Rev Saúde Públ 1996;30(5):433-7.

8. Miranda C, Massa JL, Marques CCA. Sensoriamento remoto orbital como recurso para análise da ocorrência da leishmaniose tegumentar americana em localidade urbana da região Sudeste do Brasil. Rev Saúde Públ 1998;32(5):455-63.

9. Camargo-Neves, VLFC. Características da transmissão da leishmaniose tegumentar americana no Estado de São Paulo, Brasil. Dissertação. São Paulo: USP, 1999.

10. Roberto ACBS, Lima AP, Peixoto PR, et al. Avaliação da terapia com antimoniato de N-metil glucamina e de notificação de leishmaniose tegumentar. An bras Dermatol 1997;72(2):129-3.

11. Barros GC, Sessa PA, Mattos EA, Carias VRD, Mayrink W, Alencar JTA, Falqueto A, Jesus AC. Foco de leishmaniose tegumentar americana nos municípios de Viana e Cariacica, Estado do Espírito Santo, Brasil. Rev Saúde Públ 1985;19:146-53.

12. Lima LCR, Marzochi MCA, Sabroza PC. Flebotomíneos em área de ocorrência de leishmaniose tegumentar no bairro de Campo Grande, Rio de Janeiro, Brasil. Rev bras Malar 1981;33:64-74.

13. Lima LCR, Marzochi MCA, Sobroza PC, Souza MA. Observações sobre a leishmaniose tegumentar cinco anos após profilaxia. Rev Saúde públ 1988;22(1):73-7.

14. Mattos EA. Bionomia dos flebotomíneos de Perobas, município de Viana (ES), área endêmica de leishmaniose tegumentar americana. Dissertação. Belo Horizonte: Universidade Federal de Minas Gerais, 1981.

15. Souza MA, Sabroza PCT, Marzochi MCA, Coutinho SG, Souza WJS. Leishmaniose visceral no Rio de Janeiro. 1. Flebotomíneos da área de procedência de caso humano autóctone. Mem Inst Oswaldo Cruz 1981;76(2):161-68.

16. Teodoro U, Kühl JB, Thomaz-Soccol V, et al. Environmental sanitation and peridomiciliar organization as auxiliary practices for the control of phlebotomines in Paraná State, Southern Brazil. Brazilian Archives of Biology and Tecnology 1999;42(3):307-14. 17. Lima EC, Luz E, Souza LA. Leishmaniose tegumentar americana no município de Foz do Iguaçu. Rev. Méd. Paraná 1958;27(2):53-8.

18. Silveira TGV, Teodoro U, Arraes SMAA, et al. An autochthonous case of cutaneous leishmaniasis caused by Leishmania (Leishmania) amazonensis Laison \& Shaw, 1972 from the North Paraná State, Brazil. Mem Inst Oswaldo Cruz 1990;85(4):475-6. 19. Teodoro U, La Salvia $F^{o}$ V, Lima EM, Mizuta NM, Verzignassi TG, Ferreira MEMC. Leishmaniose tegumentar americana: flebotomíneos de área de transmissão no Norte do Paraná - Brasil. Rev Saúde Públ 1991b;25(2):129-33.

20. Linthicum KJ, Bailey CL, Davies FG, Tucker CJ. Detection of rift valley fever viral activity in Kenya by satellite remote sensing imagery. Science 1987;235:1656-9.

21. Camargo JB. Geografia física, humana e econômica do Paraná. 2th ed. Paranavaí: Clichetec, 1998.
22. Instituto Agronômico do Paraná. Cartas climáticas do Estado do Paraná - 1994. Londrina: IAPAR, 1994.

23. Cigolini A, Mello L, Lopes N. Paraná - quadro natural, transformações territoriais e economia. Curitiba: Renascer, 1998:128p. 24. Hermann MLP \& Rosa RO. Relevo. In: Geografia do Brasil Região Sul. Rio de Janeiro: IBGE, 1990.

25. Maack R. Geografia física do Estado do Paraná. 2 ed. Rio de Janeiro/J. Olímpio/Curitiba: Secretaria da Cultura e do Esporte, 1981;450p.

26. Leite PF \& Klein RM. Vegetação. In: Geografia do Brasil Região Sul. Rio de Janeiro: IBGE, 1990.

27. Nimer E. Clima. In: Geografia do Brasil - Região Sul. Rio de Janeiro: IBGE, 1990.

28. Teodoro U. Características ecológicas de flebotomíneos (Diptera, Psychodidae) em habitats antrópicos, município de Jussara, Paraná, Brasil. Tese. Curitiba: Universidade Federal do Paraná, 1995.

29. Engespaço. Sistema de informações geográficas SGI/INPE: Manual do usuário versão 2.5. São José dos Campos, 1990.

30. Jensen JR. Introductory Digital Image Processing: a Remote Sensing Perspective. New Jersey: Prentice-Hall, 1986p.379.

31. Cavalcante JEA, Oliveira MF, Rios AA, Freitas CEJ. Prevalência da leishmaniose tegumentar americana no Estado do Ceará no ano de 1991 e suas variações nos últimos dez anos. Rev Bras Anál Clín 1992;24(4):121-3.

32. Gomes AC. Perfil epidemiológico da leishmaniose tegumentar no Brasil. An bras Dermatol 1992;67 (2):55-60.

33. Silveira TGV, Teodoro U, Lonardoni MVC, et al. Aspectos epidemiológicos da leishmaniose tegumentar em área endêmica do Estado do Paraná, Brasil. Cad Saúde Pública 1996;12(2):37-45.

34. Brandão-Filho SP, Carvalho FG, Brito MEF, Almeida FA, Nascimento LA American cutaneous leishmaniasis in Pernambuco, Brazil: eco-epidemiological aspects in "Zona da Mata" region. In: research and control of leishmaniasis in Brazil. Proceedings of National Workshop. Recife, Fiocruz, 1993:51-7. 35. Forattini OP, Rabello EX, Serra OP, Cotrim MD, Galati EAB, Barata JMS. Observações sobre a transmissão da leishmaniose tegumentar no Estado de São Paulo, Brasil. Rev Saúde públ 1976;10:31-43.

36. Gomes AC, Santos JLF, Galati EAB. Ecological aspectos of american cutaneos leishmaniasis. 4. Observations on the endophilic behavior of the sandfly and the vectorial role of psychodopygus intermedius in the Ribeira Valley region of the S. Paulo State, Brasil. Rev Saúde públ 1986;20(4):280-7.

37. Teodoro U, La Salvia F ${ }^{\circ}$ V, Lima EM, et al. Observações sobre o comportamento de flebotomíneos em ecótopos florestais e extraflorestais, em área endêmica de leishmaniose tegumentar americana, no norte do Estado do Paraná, sul do Brasil. Rev Saúde Públ 1993b;27(4):242-9.

38. França F, Lago EL, Tada S, et al. An outbreak of human Leishmania (Viannia) brasiliensis infection. Men Inst Oswaldo Cruz 1991;86(2):169-74.

ENDEREÇO PARA CORRESPONDÊNCIA: / MAILING ADDRESS:
Airton Pereira Lima
Rua Humaitá, 456
Cianorte PR $87200-000$
Tel: (44) 629-1915
E-mail: airton.pl@uol.com.br

ENDEREÇO PARA CORRESPONDÊNCIA: / MAILING ADDRESS:

Cianorte PR 87200-000

E-mail:airton.pl@uol.com.br 